\title{
РЕЦЕНЗІї
}

DOI: 10.34015/2523-4552.2020.4.17

УдК 343.6

\author{
Вознюк А. A., \\ доктор юридичних наук, професор, \\ завідувач наукової лабораторії 3 \\ проблем протидії злочинності \\ Національної академії внутрішніх \\ cправ \\ ORCID: 0000-0002-3352-5626
}

\section{КРИМІНАЛЬНІ ПРАВОПОРУШЕННЯ ПРОТИ ВОЛІ, ЧЕСТІ ТА ГІДНОСТІ ОСОБИ: ФУНДАМЕНТАЛЬНЕ ДОСЛІДЖЕННЯ У КРИМІНАЛЬНО-ПРАВОВОМУ ТА КРИМІНОЛОГІЧНОМУ ВИМІРІ}

Рец. на кн.: Андрушко А. В. Теоретико-прикладні засади запобігання та протидії злочинам проти волі, честі та гідності особи: монографія. Київ : Baime, 2020. 560 c.

Актуальність теми монографічного дослідження Андрушка Андрія Васильовича не викликає сумнівів. По-перше, у кримінальноправовій та кримінологічній науці дотепер відсутнє комплексне дослідження кримінальних правопорушень проти волі, честі та гідності особи. По-друге, у правозастосовній практиці виникає чимало питань, пов'язаних з кримінально-правовою кваліфікацією вказаних посягань, котрі потребують глибокого наукового аналізу. Цілком очевидно також, що ефективне запобігання зазначеним посяганням можливе лише за умови створення належного теоретичного підгрунтя.

Наукова праця молодого, талановитого та перспективного науковця $є$ фундаментальною, оскільки включає системну розробку кримінальних правопорушень проти волі, честі та гідності особи у кримінально-правовому та кримінологічному вимірах, яка стане в нагоді не одному поколінню вчених криміналістів. Без перебільшення відмічу, що за формою, змістом та обсягом наукові результати Андрія Васильовича відповідають рівню не однієї, а двох дисертацій на здобуття наукового ступеня доктора юридичних наук.

Структура монографічного дослідження не викликає заперечень. Викладені в роботі положення та висновки належним чином обгрунтовані, є новими й такими, що мають значення не лише для кримінальноправової та кримінологічної науки, а й для правозастосовної практики. Окремі положення є дискусійними, але в той же час нетривіальними й такими, що спонукають до роздумів та подальших досліджень. 
Автор глибоко дослідив історико-правові аспекти кримінальної відповідальності за посягання на волю, честь та гідність особи, проаналізував еволюцію поглядів на вказані злочини в доктрині кримінального права другої половини XIX - початку XXI століття, надав розгорнуту кримінально-правову характеристику кримінальних правопорушень проти волі, честі та гідності особи.

Чимала увага в роботі приділена кримінологічним аспектам кримінальних правопорушень проти волі, честі та гідності особи. Автор з'ясував кількісно-якісні показники вказаних діянь, на підставі вивченої емпіричної бази дослідив особу злочинця, який вчиняє такі діяння, проаналізував детермінаційний комплекс аналізованих кримінальних правопорушень та запропонував систему заходів, спрямованих на запобігання їм.

Підкреслимо, що висновки та інші положення монографії грунтуються на вивченні достатньо репрезентативної емпіричної бази. Йдеть- ся, зокрема, про офіційні статистичні дані Генеральної прокуратури України, Міністерства внутрішніх справ України, Державної служби статистики України, проаналізовані автором матеріали 753 кримінальних проваджень, анкетування 200 суддів і працівників правоохоронних органів тощо. Величезну увагу в роботі приділено також зарубіжному досвіду кримінально-правової протидії злочинам проти волі, честі та гідності особи. 3 цією метою автором вивчено кримінальні закони 63 зарубіжних держав.

Таким чином, рецензована монографія А. В.Андрушка $\epsilon$ не лише завершеним фундаментальним науковим дослідженням, але й гідним прикладом для наслідування, що має колосальне значення для розв'язання проблем побудови якісних кримінально-правових норм проти волі, честі та гідності особи, уточнення правил кваліфікації правопорушень цієї категорії, а також розроблення тактики й стратегії запобігання та протидії їм не лише в Україні, але й за її межами. 